\title{
Bacterial Contamination of Urban Water Wells in the Nuwayri Region of Beirut - Lebanon
}

\author{
Houssam Al Koussa ${ }^{1}$ and Tarek Nawas ${ }^{1}$ \\ 1: Natural Sciences Department, School of Arts and Sciences, Lebanese American University, Beirut - \\ Lebanon
}

\begin{abstract}
Nine water wells serving nine different building residents in the Bourj Abi Haydar- Nuwayri region in Beirut (Lebanon) were tested for contamination with Gram negative bacteria by standard methods. The samples were obtained from the first outlet from the well that was available for the collection of the water by the users. Six of the wells grew numerous types of bacteria including coliforms and non-fermentative organisms. Two wells grew Salmonella and Shigella species respectively, while a third was recognized for the very big number of CFUs growing from the sample obtained. The three wells that did not grow organisms were obtained from a central tank in each building that was regularly chlorinated and from which the users collected their water supply, when needed. The results show that the substantial contamination obtained, prohibits the use of well-water in the region for any use, without proper treatment to avoid undesired medical consequences. Further studies and intervention of the public health authorities are needed, as the results of this study indicate that this problem seems to be of a bigger magnitude than presumed.
\end{abstract}

Keywords: Bacterial Contamination, Detection of coliforms, Drinking water, Groundwater, Urban water supplies, Well water.

\section{Introduction}

Water is supplied to consumers from various sources including water wells, which are structures formed by digging, driving, or drilling in the ground to access groundwater.

There are different types of water wells. The most ancient type of wells is the dug well, that is manually dug in the ground with a shovel or a pick. The well is continuously dug until water flowed inside it. Then, the well was lined with stones or bricks to prevent it from collapsing [1].

The driven well, a more commonly used type of well, is made by driving a small diameter pipe into soft ground such as sand. The pipe is then attached to a filter at the bottom that filters out sand and other particles. Like the dug wells, driven wells can only tap to the shallow water, because the source of water is close to the surface. The disadvantage of shallow water is that it is always exposed to contamination from surface pollutants [1].

The most modern type of well is the drilled well, in which a drill, attached to a big truck, keeps on drilling the ground and smashing the rocks, until it reaches the existent ground water. The advantage is that drilled wells can go deep in the ground (sometimes to more than 300 meters). Often, a pump is placed at the bottom to push water up to the surface $[1,2]$.

Unless the quality of the water obtained from water wells used regularly by some communities is compatible with acceptable standards, the health of the users can be endangered and the image of that community might be affected leading to certain delay in its economic development.

Most studies on contamination of water focused mainly on publicly distributed drinking water or packaged (or bottled) drinking water, commercially available for the public. Fewer studies were performed to determine the contamination of the water obtained from water wells. That water is rarely, if ever, used for drinking under normal conditions as it is expected not to be suitable for human consumption. Well water is, however, used for different purposes in houses and may therefore, be abused, thus endangering the health of the users, especially the young, the elderly and the sick [3].

Although Lebanon is considered rich in its water beds, yet, the improper collection, storage and distribution of the available water led many communities, even in big cities, to be partially dependent on drilled well water to fulfill their day to day needs for water. For a period of 8 months (July, 2015 till March, 2016) Lebanon suffered from a garbage collection crisis. Most of the streets in Beirut, the capital (and other cities), were cluttered with garbage that was not collected, sometimes for weeks. The problem was worse during the rainy season, when a lot of the garbage was carried about by rain water. It was presumed that a lot of the garbage content may have leaked deep to reach the ground water.

The aim of this study was to detect bacterial contamination of water samples, collected from private buildings' supply wells, located in a particular residence region in Beirut. Of the microbes, the coliforms which 
are a group of gram negative bacteria, are mainly looked for as their presence in water samples is indicative of environmental contamination and in the case of Escherichia coli, fecal contamination [1].

\section{1-Sources of samples:}

\section{Methods}

Nine well-water samples from 9 different buildings in the Bourj Abi Haydar- Nuwayri residence region in Beirut were obtained (Fig. 1). All the randomly selected wells were drilled wells about 80 meters deep, that had pumps to carry the water to storage vessels from where it was then either distributed to the residents through the regular water distribution pipes, or was available for them to use whenever needed.

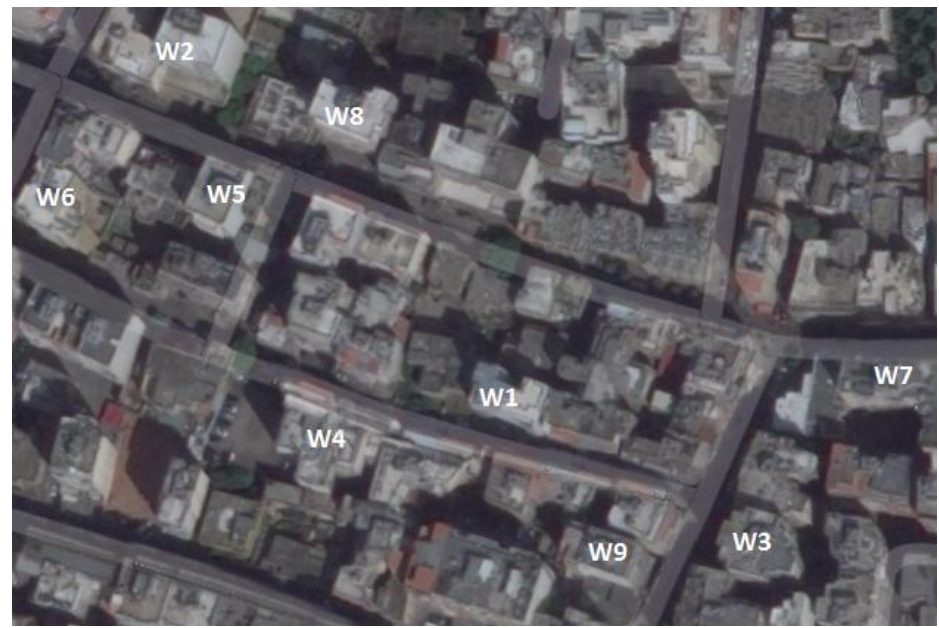

Figure 1: The random buildings from which the wells were selected for the study in the Bourj Abi HaydarNuwayri district - Beirut (Courtesy of Google Earth)

\section{2- Collection of samples:}

The $50 \mathrm{mls}$ samples were collected in sterile containers from the first outlet (faucet) closest to the well and accessible to the residents of the randomly chosen buildings. It was common that such an outlet in all buildings was a faucet from the collection tank in which the well water was pumped in regularly. A mobilized cooler was used to transport the samples in a cold environment to the microbiology laboratory where they were put in a refrigerator until their processing, within the shortest period of time.

\section{3- Processing of samples:}

The membrane filtration (MF) technique, a fully accepted and approved method to detect coliforms from water samples which was recommended by the USA Environmental Protection Agency and other reference bodies [4,5], was the method used in this study. Each 50mls water sample was filtered through a $0.45 \mu \mathrm{m}$ pore size cellulose ester membrane filter. The filters were immediately removed aseptically and placed on a MacConkey agar plates, the medium commonly used to detect the growth of Gram negative bacteria from water samples [5]. The plates were then incubated for 24 hours at $35^{\circ} \mathrm{C}$. The total bacterial and coliform count was obtained, after incubation, and the different types of colonies growing were isolated on freshly prepared trypticase soy agar plates (TSA) in order to confirm their purity and then their identity.

\section{4- Identification of isolates}

After confirming by the Gram's stain that the isolated organisms were gram negative bacilli, the identification of the different isolates was done in two stages. The preliminary set of standard tests included: catalase and oxidase production tests, Kligler's iron agar, the IMVIC battery of tests (Indole, Methyl red, Voges Proskauer, and Citrate tests) and the motility test; all of which were performed as recommended [6]. The definitive identification of these isolates, however, was obtained using the API 20E strips (BioMérieux France), and performed as recommended by the manufacturer.

\section{Results}

Table 1 shows the total Gram negative bacterial and coliform counts obtained from the different wells and the organisms that were isolated from each sample of each well. As is clear from the Table, three specimens obtained from the wells numbered 2, 3 and 5 did not grow any organism, whereas all the others showed growth of considerable numbers of colony forming units. Whereas the samples from well 7 grew only non-fermentative organisms, samples from all the other wells samples from wells: 1, 4, 6, 8 and 9, grew coliforms and at least one 
other organism. Well 6 was recognized for growing a very big number of CFUs, while wells 1 and 9 were distinguished by growing colonies of Salmonella sp. and Shigella sp. respectively

Table 1: The total Gram negative bacterial and coliform counts obtained from the different wells included in the study (CFUs/50 mls.), and the organisms that were isolated from each sample. NG: no growth.

\begin{tabular}{|l|l|l|l|}
\hline Sample & $\begin{array}{l}\text { Total Gram Negative } \\
\text { Count }\end{array}$ & Coliform Count & Isolated organisms \\
\hline Well 1 & 10 & 1 & Hafnia alvei, Salmonella sp., Acinetobacter sp. \\
\hline Well 2 & NG & NG & - \\
\hline Well 3 & NG & NG & - \\
\hline Well 4 & 79 & 11 & Enterobacter cloacae, nonfermenters, \\
\hline Well 5 & NG & NG & - \\
\hline Well 6 & $>300$ & $>100$ & Enterobacter cloacae, Morganella morganii, nonfermenters \\
\hline Well 7 & 68 & 0 & nonfermenters \\
\hline Well 8 & 110 & 8 & Enterobacter cloacae, nonfermenters, Proteus vulgaris \\
\hline Well 9 & 57 & 7 & Citrobacter freundii, Shigella sp., nonfermenters \\
\hline
\end{tabular}

\section{DISCUSSION}

Water quality refers to the chemical, physical, radiological and biological characteristics of the water being used. Its importance is to see whether the water conditions fit the requirements for the human needs or not. If not then the water would be considered contaminated and must not be used for drinking and/or food preparation or else it will lead to illnesses, a lot of suffering and maybe death [2]. The correlation between the ingestion of polluted/contaminated water and the incidence of diseases such as gastro-enteritis and some helminthic diseases, has long been established [7,8]. Thus, the continued consumption of such water, mainly out of ignorance should be discouraged or legally prohibited.

The common types of contaminants include microbes and various chemicals like metals and minerals, pesticides, fertilizers and petroleum products [4]. These contaminants are due to agricultural activity, industrial activity household chemicals, leaking sewer lines, septic systems, irregular sanitary problems, improperly protected well heads that allow contaminated surface water to drain into the aquifer along the outer well casing [9]. It should be noted, however, that a water sample's taste, odor or color aren't enough to indicate its quality, for the most dangerous contaminants are usually note detected by the senses. Such contaminants can only be detected by proper testing. Drinking water contaminated with these chemicals is a health hazard.

Contaminated groundwater is the most commonly reported source of waterborne disease in the United States [10]. Contamination of ground and private well (household supply) water was reported from many states $[10,11,12,13,14]$ and over long periods of time [11,12]. The problem, however, turned out to be global as similar findings were reported from Europe [15, 16, 17, 18], Africa [19, 20, 21, 22], South America [23, 24] and Asia [16, 17, 25]. Assessing the seriousness of the problem and its consequences, standards, as well as, guidelines for construction of wells, regular monitoring of well water through proper sampling, testing and decontaminating, in addition to use of well water were introduced and enforced [3, 13, 19, 26, 27, 28, 29].

Our exploration indicated that the only study related to well water contamination in Lebanon, was done in 1999, by the American University of Beirut's Water Resources Center in cooperation with the United Nations environmental program, that conducted that study to assess the groundwater chemical quality in Lebanon [30]. From 13 different regions 31 groundwater samples were collected and analyzed for the presence of 16 pesticide compounds. The results showed that mainly along the coast, well water had a high nitrate concentration, more than double of that recommended by the WHO [2]. No reports on bacterial contamination of water in domestic wells were found. The aforementioned study clearly indicated that water from wells, in Lebanon, were chemically contaminated, a reason why this study was needed to shed a light on another side of the issue, whether the often used water from wells was also contaminated by bacteria.

Most bacteria entering the ground surface along with rain water are usually filtered out as the water seeps through the soil. Several strains of bacteria can survive a long time and find their way into the ground water by moving through coarse soils, shallow fractured bedrock, quarries, sinkholes, inadequately grouted wells or cracks in the well casing. Insects or small rodents can also carry bacteria into wells with inadequate caps or seals. Coliform bacteria are naturally occurring in soil and are found on vegetation and in surface waters. However, water from a well properly located and constructed should be free of coliform bacteria [9].

The presence of Gram negative bacteria, mainly coliforms, in the sampled wells of this study, was detected by using the recommended membrane filtration (MF) technique [4, 5]. The use of MacCokey agar in the MF technique, instead of any other medium, to isolate the Gram negative organisms from the water sample was favorable as the organisms isolated were very similar to those isolated from contaminated wells elsewhere, using very specialized media $[31,32,33,34,35]$.

Six of the 9 wells included in the study, grew the coliforms: Enterobacter cloacae, Cirtobacter freundii, and Hafnia alvei, indicating environmental contamination. These organisms were isolated with many 
others, mainly non-fermentative bacteria that also reside in soil, but in principle should not be present in the water of the domestic wells. It was very significant, however, to isolate: Salmonella sp., Proteus mirabilis and Shigella sp. From 3 wells (W1, W8 and W9 in Fig. 1), indicating fresh fecal contamination, although the usual indicator of fecal contamination (Escherichia coli) was not isolated.

In investigating the reason of not getting any growth in 3 out of the 9 wells (W2, W3 and W5 in Fig. 1), it was found out that the same water decontamination process was practiced by the tenants' committees of the 3 buildings. A standard chlorine containing disc was put regularly in the central tank from which the tenants took the water. The discs were found to be supplied by the same company, but the amount of chlorine provided by these discs was not checked by any test. The absence of Gram negative bacteria, in these wells, proved that the water was cleared from these bacteria in these 3 buildings. No tests were done to detect the concentration in the storage tanks in these buildings. It was also noted, that no regular tests for biological, or chemical contamination were performed by these (and all the other) buildings included in this study. Another issue to point out was that this study aimed at specifically looking for contamination by Gram negative organisms, yet, it was proved that Gram positive organisms, like enterococci can also play a major role in the contamination of water wells.

\section{Conclusion}

This study proved that at least in the region tested, well water bacterial contamination was evident. It is presumed that many factors contributed towards this including: The cluttering of garbage for long months in the streets of the region especially during the rainy season, the geological nature of the area which probably included fractured rock, allowed the contaminating organisms of surface waters to reach the ground water below. There was also evidence that the unattended sewage system in the region was seeping into the ground water.

Private water supplies in domestic wells in Lebanon, are not under any official public health sanitary control, a reason why further studies are needed to detect the extent of the contamination in the numerous wells used extensively all over Lebanon, even in big cities. Once this has been assessed, it would be expected from the public health authorities to actively intervene to ensure that, at least, proper sanitary methods are introduced and regularly implemented to ensure the safety of the users.

\section{References}

[1] U.S. Environmental Protection Agency, Private drinking water wells, Office of Ground Water and Drinking Water, 2005. Available online at: http://www.epa.gov/safewater/privatewells/Index2.html or: https://www.epa.gov/privatewells/about-private-water-wells

[2] World Health Organization. Guidelines for drinking-water quality: Clear Water for healthy world, Water for health, 1, (WHO. 2010).

[3] South Eastern Regional Zoonoses Committee, Advice for private well owners: How well is your water. Department of Agriculture \& Food, Department of Communications, Marine \& Natural Resources, (Ireland, The City Council of Waterford and The County Councils of Carlow, Kilkenny, Tipperary South Riding, Waterford and Wexford. 2002). Available online at: http://www.hse.ie/eng/services/Publications/Environmentalhealth/How\%20Well\%20is\%20your\%20Water.pdf

[4] U.S. Environmental Protection Agency, 2002c, Method 1604- Total coliforms and Escherichia coli in water by membrane filtration using a simultaneous detection technique (MI Medium): Office of Water, September 2002, EPA 821-R-02-024, 18 p.

[5] A. Rompré, P. Servais, J. Baudart, M.R. de-Roubin and P. Laurent, Detection and enumeration of coliforms in drinking water: current methods and emerging approaches. J Microbiol. Methods, 49(1), 2002, 31-54. Available online at: https://doi.org/10.1016/S0167-7012(01)00351-7

[6] S.T. Cowan, and K.J. Steel. Identification of medical bacteria. (Cambridge, MA: University Press, 1965).

[7] R. Feachem, M. McGarry and D. Mara, Water, wastes and health in hot climates (Chichester, John Willy and Sons, 1983).

[8] K. Gibbs, 1987. The Turbulence in Water, in Pickford, J. (Ed.), Developing world water (Hong Kong, Grosvenor Press, 1987 ) 46.

[9] Board of health, Bacterial contamination in well water - PUB-DG-003 (Wisconsin. USA, Wisconsin Department of Natural Resources, 2009). Available at: http//www.co.winnebago.wi.us/health/units/environmental-health/hazards/bacteria-contaminationwell-water

[10] T.T. Fong, L.S. Mansfield, D.L. Wilson, D.J. Schwab, S.L. Molloy and J.B. Rose1, Massive microbiological groundwater contamination associated with a waterborne outbreak in Lake Erie, South Bass Island, Ohio, Environmental Health Perspectives, 115 (6), 2007,856-864

[11] A. Roman-Mas, M.W. Bennett and K.G. Hamilton, Reconnaissance of ground-water quality at selected sites in Bedford and Coffee Counties, 1 (Tennessee, June and July 1991: U.S. Geological Survey, 1991) Open- File Report, 91-510.

[12] T. M. Zimmerman, M. L. Zimmerman, and B.D. Lindsey. Relation between selected well-construction character and occurrence of bacteria in private household-supply wells, south central and southeastern Pennsylvania. (U.S. Geological Survey: Water-Resources Investigations, 2001), Report 01-4206

[13] K. Begos, 4 states confirm water pollution from drilling. USA Today. (The Associated Press, USA. Jan. 5, 2014). Available online at: http://www.usatoday.com/story/money/business/2014/01/05/some-states-confirm-water-pollution-from-drilling/4328859/

[14] D.S. Francy, D.R. Helsel, and R. A. Nally, Occurrence and distribution of microbiological indicators in groundwater and stream water: Washington, D.C., Water Environment Research, 72 (2), 2000, 152-161.

[15] S. Buchan and A. Key. Pollution of ground water in Europe. Bull World Health Organ. 14(5-6), 1956, 949-1006. PMCID: PMC2538141

[16] H. Jones, P. Visoottiviseth, M.K. Bux, R. Födényi, N. Kováts, G. Borbély and Z.Galbács, Case reports: arsenic pollution in Thailand, Bangladesh, and Hungary.Rev Environ Contam Toxicol., 197, 2008, 163-87.

[17] N. Litvinov, Water pollution in the USSR and in other Eastern European countries. Bull World Health Organ. 26, 1962, 439-63.

[18] A. Key, Pollution of surface water in Europe.Bull World Health Organ, 14 (5-6), 1956, 845-948. 
[19] I.I. Mile, J.A. Jande and B.I. Dagba, Bacteriological contamination of well water in Makurdi town, Benue state, Nigeria, Pakistan Journal of Biological Sciences, 15, 2012, 1048-1051. (DOI: 10.3923/pjbs.2012.1048.1051 )

[20] I. Ouedraogo, P. Defourny and M. Vanclooster. Mapping the groundwater vulnerability for pollution at the pan African scale. Science of the Total Environment. 544, 2016, 939-953, Available online at: https://doi.org/10.1016/j.scitotenv.2015.11.135.

[21] T. Mkandawire, Quality of groundwater from shallow wells of selected villages in Blantyre District, Malawi, Physics and Chemistry of the Earth, 33 (8), 2008, 807-811

[22] J.E.G. Mdoe and J. Buchweishija, The Quality of groundwater from wells in squatter and non-squatter settlements in Dar es Salaam city, Tanzania, International Journal of Engineering Research \& Technology, 3 (9), 2014, 1442-1445.

[23] R. Fusconi and M.J.L. Godinho, Bacteria and protozoa populations in groundwater in landfill area in São Carlos, SP. Revista de

[24] F. Lucena, F. Ribas, A.E. Duran, S. Skraber, C. Gantzer, C. Campos, A. Morón, E. Calderón and J. Jofre, Occurrence of bacterial indicators and bacteriophages infecting enteric bacteria in groundwater in different geographical areas. Journal of Applied Microbiology, 101, 2006, 96-102. doi:10.1111/j.1365-2672.2006.02907.x

[25] CK. Jain. Arsenic contamination in ground water: Indian scenario.Indian J Environ Health. 44(3), 2002, 238-43.

[26] The Penn State College of Agricultural Sciences research and extension programs. Safeguarding wells and springs from bacterial contamination, (The Pennsylvania State University, 2017). Code EC345. Available online at: http://extension.psu.edu/naturalresources/water/drinking-water/cisterns-and-springs/safeguarding-wells-and-springs-from-bacterial-contamination

[27] International Organization for Standardization, Water quality-sampling-Part 11: Guidance on sampling of ground waters. Standard ISO 5667-11, (Geneva, International Organization for Standardization, 2009a)

[28] World Health Organization, Guidelines for drinking-water quality - WHO Library Cataloguing-in-Publication Data, 1. Potable water - standards. 2.Water - standards. 3.Water quality - standards. 4.Guidelines. I., 4th ed., World Health Organization. (NLM classification: WA 675) ISBN 9789241548151

[29] The State of Connecticut Department of Public Health. Bacteria in private drinking water wells (Adapted from Healthy Drinking Waters for Rhode Islanders, University of Rhode Island. Cooperative Extension, April 2003). Environmental Health Section. Private Well Program. Publication No. 4: 1-4. 2009. Available online at: :http://www.ct.gov/dph/lib/dph/environmental_health/pdf/04_bacteria_in_private_drinking_water_wells_04-09.pdf

[30] American University of Beirut Water Resources Center, Lebanon state of the environment Report, Ecosystem Management by the United Nation Environmental Program. (Beirut, AUB Water Resources Center, National SOE, 1999), Chapter 8.

[31] P. Kämpfer, A. Nienhüser, G. Packroff, F. Wernicke, A. Mehling, K. Nixdorf, S. Fiedler, C. Kolauch and M. Esser, Molecular identification of coliform bacteria isolated from drinking water reservoirs with traditional methods and the Colilert-18 system. Int $\mathbf{J}$ Hyg Environ Health 211, 2008, 374-384. doi:10.1016/j.ijheh.2007.07.021.

[32] T.C. Covert, L.C. Shadix, E.W. Rice, J.R. Haines and R.W. Freyberg, Evaluation of the autoanalysis Colilert test for detection and enumeration of total coliforms. Appl Environ Microbiol 55, 1989, 2443-2447.

[33] K.P. Brenner, C.C. Rankin, Y.R. Roybal, G.N. Jr Stelma, P.V. Scarpino and A.P. Dufour. New medium for the simultaneous detection of total coliforms and Escherichia coli in water. Appl Environ Microbiol 59, 1993, 3534-3544.

[34] C. Bernasconi, G. Volponi and L.Bonadonna, Comparison of three different media for the detection of E. coli and coliforms in water. Water Sci Technol 54, 2006, 141-145. doi:10.2166/wst.2006.460.

[35] T.A. Freier and P.A.Hartman, Improved membrane filtration media for enumeration of total coliforms and Escherichia coli from sewage and surface waters. Appl Environ Microbiol 53, 1987, 1246-1250. 